\title{
Research on the Quality of International Cooperation in Higher Vocational Colleges
}

\author{
Hua Liu \\ Dalian vocational \& technical college 116035
}

Keywords: Higher Vocational Colleges; Quality of Cooperative Education

\begin{abstract}
China has formulated relevant incentive policies for international cooperation in higher vocational colleges. Therefore, the quality of international cooperation in higher vocational colleges is also constantly improving. However, it is undeniable that there are many deficiencies and problems in the international cooperation in higher vocational colleges. Therefore, this paper conducts relevant research and discussion on the quality of international cooperation in higher vocational colleges.
\end{abstract}

\section{Introduction}

International cooperative teaching can promote the exchanges between higher vocational colleges and other foreign schools, and is conducive to promoting the introduction of advanced educational concepts and rich educational resources in higher vocational colleges in China. It is an important measure to improve the educational level of our country. However, with the impact of multiculturalism, the international cooperation in higher vocational colleges has gradually revealed many problems. It is necessary to study the quality of international cooperation in higher vocational colleges and further improve the level of education in China.

\section{The Status Quo of International Cooperation in Running Schools in Higher Vocational Colleges}

The international cooperation in higher vocational colleges in China has a history of nearly 20 years. Although the time is relatively short, the effect is quite outstanding. At this stage, the international cooperation in running schools in higher vocational colleges in China has gradually realized that the teaching level is clear, the content of running schools is rich and diverse, and teachers and students are jointly trained.

The first point is to discuss the teaching hierarchy clearly. The goal of cultivating talent is different, and the form of education will be different. Some pay attention to the award of academic qualifications, some do not attach importance to academic qualifications, but attach importance to cultivating students' practical ability. Some also use foreign funds and technology to train students in a short period of time. The emergence of these phenomena indicates that the international cooperation teaching at this stage has gradually matured, and it has gradually become targeted and hierarchical.

The second point is that the content of cooperative education is gradually enriched. At this stage, the international cooperation in higher vocational colleges in China has special projects for foreign advanced technology training, as well as the absorption of foreign advanced educational concepts and methods to improve the level of education in China. These are, to a certain extent, enriching the content of cooperative education. Cooperative school-running content will also better realize the value of cooperative education, and also attract students' enthusiasm for learning, improve teaching efficiency, and promote the improvement of teaching level in China.

The third point is to take care of the teachers and students to cultivate together. With the improvement of the economic level, people's requirements for education level are getting higher and higher. Many parents, teachers who require their children must have a study abroad experience or a higher degree. Therefore, in cooperation with schools, it is necessary not only to train students in the knowledge transfer and related abilities, but also to train teachers. In China, it is not 
uncommon to hire foreign teachers. The reason for hiring foreign teachers is not only to let students understand different ideas in different cultural backgrounds, but also the educational abilities of Chinese teachers. Therefore, it is very necessary to improve the overall faculty of China by means of cooperation in running schools.

The fourth point is to achieve school-enterprise cooperation. With the accelerating process of globalization, the international cooperation in higher vocational colleges has gradually achieved a seamless connection from talent cultivation to corporate work. To put it simply, talents trained in international cooperation can directly face-to-face contact with foreign companies, and can also directly enter foreign companies for internships after completing their studies. This will not only improve the professional quality of students, but also greatly reduce the employment pressure of students in higher vocational colleges.

\section{Problems in International Cooperation in Running Schools in Higher Vocational Colleges}

\subsection{Slow Improvement of the Level of International Cooperation in Higher Vocational Colleges}

At this stage, the level of international cooperation in higher vocational colleges is slower. The reason is that the school does not strictly control the foreign language level of students. As we all know, international cooperation in running schools is in line with the track. Many teaching contents involve foreign languages. If students do not have a good command of foreign languages, it is difficult to play the value of international cooperative teaching, and it is difficult to promote the smooth progress of relevant teaching courses. In addition, some cooperative schools are tempted by the interests of money, and have not investigated the qualifications and education level of foreign institutions, and directly cooperated in running schools. This will not only damage the reputation of the school, but also affect the level of cooperation in running schools.

\subsection{International Cooperation in Vocational Colleges is Concentrated and Repeated}

Studies have shown that the international cooperation in higher vocational colleges in China is mainly concentrated in economic management and electrical and electronic fields. This concentrated and repetitive profession will make the talents in these fields saturated, not only cannot reduce pressure, but also will increase employment pressure. In addition, the profession is not able to meet the needs of students. Each student has his or her own interests and hobbies. Some students like philosophy, some like literature, and these repetitive and concentrated majors can't meet the needs of students, which may lead to a decline in enrollment. It is not conducive to promoting the good development of international cooperation in higher vocational colleges.

\subsection{Problems in the Management of Foreign Education in International Cooperation in Higher Vocational Colleges}

There is a prominent problem in the management of foreign education in the international cooperative education of higher vocational colleges, that is, the identity and qualifications of foreign teachers are not strictly examined. This will lead to some foreigners who do not have the qualifications of teachers to join the team of foreign teachers. Such a miscellaneous phenomenon has seriously affected the improvement of the overall level of foreign teachers and the improvement of teaching quality. Then there is no standardized and scientific management system. Due to differences in the thinking and living habits of Chinese and foreigners, many international cooperative schools have not established relevant management systems for foreign teachers. The so-called no rules, not a square, if there is no relevant system to restrict the behavior and teaching content of foreign teachers, it is very likely to lead to some vicious incidents.

\subsection{International Cooperation in Higher Vocational Colleges Attaches Importance to Technical Training and Neglects Theoretical Teaching}

The international cooperative education of many higher vocational colleges in China attaches great 
importance to the technical training of students, and some will directly quote foreign teaching materials and teaching methods. As we all know, there are differences between Chinese and Western cultures, and there are certain differences in thoughts and learning methods. If you do not start from the actual learning situation of students, the direct introduction of teaching materials and teaching methods can very much lead students to lose interest in teaching content and affect the quality of teaching. Then there is the neglect of the transfer of theoretical knowledge. Theoretical knowledge, laying a solid foundation for students' learning, neglecting the teaching of theoretical knowledge, will make students have no deep understanding of relevant knowledge. Like the theory of economic management bias, if only the student management strategy is told, and the true meaning of the relevant strategy is not told, it will affect the effect of teaching.

\section{Optimization Ways and Suggestions for the Quality of International Cooperation in Higher Vocational Colleges}

\subsection{Optimization Ways and Suggestions for the Quality of International Cooperation in Higher Vocational Colleges}

The international cooperation in higher vocational colleges is to learn advanced foreign technology and to learn advanced foreign culture and ideas. The simple introduction of technology and ideas can not improve the teaching level of our country. Only by introducing and absorbing, can we cultivate talents with all-round development and be able to embark on the road of higher vocational education with Chinese characteristics.

\subsection{Emancipate the Mind and Actively Explore New Modes of Cooperation in Running Schools}

Exploring the new cooperative school model is the first step towards innovation. Only innovation can develop and be able to progress. Of course, innovation itself should also be within the scope permitted by Chinese law. It is important not to take the opportunity to take some unusual roads. For example, the scientific outlook on development can be applied to teaching. The scientific concept of development attaches importance to starting from reality, innovating development concepts and pursuing seeking truth from facts. Therefore, the cooperative school-running model should also follow the relevant principles, which not only makes the cooperative school-running model more responsive to the needs of the times, but also makes the cooperative school-running model more Chinese.

\subsection{Do A Good Job in the Evaluation of Cooperative Education}

Do a good job in the evaluation of cooperative education, and be able to find out the problems in the cooperation in running schools in time. Only when problems are discovered can they be resolved before they can make progress. In addition, you can gain valuable cooperation in running schools. Education itself needs to keep pace with the times, because the teaching content and teaching philosophy will change with the development of the times. This means that cooperation in running a school cannot be static, and it needs to be properly rectified in the new era. The valuable experience in running a school can enable the cooperative school to better adapt to the needs of the new situation. Therefore, it is of utmost importance to do a good job in evaluating the cooperation in running schools.

\subsection{Studying Excellent Foreign Campus Culture}

Different campus cultures are derived from different races and cultures. Higher vocational colleges in China should learn and absorb the excellent foreign campus culture, so that the cultural gap between China and the West can be narrowed, and the gap between educational levels can be narrowed. For example, American universities have Greek life. Simply speaking, they are American brotherhoods and sisterhood cultures. Some of them are mischievous, some are more professional academic seminars. In general, they enrich the campus life of American students. 


\subsection{Promote the Scientific Allocation of Material Resources}

As we all know, higher vocational colleges mainly train technical talents, and training is the main content of related education. Material resources such as training venues and teaching-related equipment directly affect the quality of teaching. Therefore, the international cooperation in higher vocational colleges should pay attention to the scientific allocation of material resources.

\section{Conclusion:}

The research on the quality of international cooperation in higher vocational colleges is to discover the problems in the cooperative education, and then actively seek strategies to solve the problems. It is hoped that through the analysis of this article, the quality of cooperation in higher vocational colleges will be promoted.

\section{References:}

[1] Wang Lianxiao. Research on the Construction of Quality Assurance System for Sino-foreign Cooperation in Higher Vocational Education-Taking Zhejiang Vocational and Technical College of Industry as an Example[J]. Adult Education. 2015(02)

[2] Qin Chuan, Qi Hongli, Xie Jinling. Taking the road of international cooperation and exchanges to create a brand of higher vocational education [J]. China Higher Education. 2016(22)

[3] Fan Yanjun, Xia Quanxing. Strengthening the cooperation between school and enterprise to cultivate the key competence of vocational students[J]. Vocational Education Forum. 2017(13)

[4] Yuan Weiguo. New Thoughts on Internationalization of Higher Vocational Colleges under the Background of Globalization_-From the Employment Problem of Higher Vocational Graduates [J]. China Vocational and Technical Education. 2017(10) 